\title{
Evaluasi Kualitas Hidup Pasien Parkinson Berdasarkan Terapi Berbasis Levodopa
}

\author{
Yasinda Oktariza ${ }^{1,2}$, Lia Amalia ${ }^{1}$, Sobaryati ${ }^{3}$, Media Y. Kurniawati ${ }^{4}$ \\ ${ }^{1}$ Kelompok Keahlian Farmakologi-Farmasi Klinik, Sekolah Farmasi, Institut Teknologi \\ Bandung, Bandung, Indonesia, ${ }^{2}$ Program Studi Farmasi, Fakultas MIPA dan Kesehatan, \\ Universitas Muhammadiyah Riau, Pekanbaru, Indonesia ${ }^{3}$ Departemen Neurologi, \\ Rumah Sakit Hasan Sadikin, Bandung, Indonesia, ${ }^{4}$ Departemen Neurologi, \\ Rumah Sakit Umum Daerah Cibabat, Cimahi, Indonesia
}

\begin{abstract}
Abstrak
Levodopa telah menjadi pilihan utama dalam pengobatan penyakit Parkinson selama lebih dari 40 tahun. Pemberian levodopa sering dikombinasi dengan obat lain untuk meningkatkan bioavailabilitas maupun efektivitasnya. Namun, di sisi lain, penggunaan levodopa dalam jangka panjang dapat menyebabkan efek samping berupa komplikasi motorik yang dapat menurunkan kualitas hidup pasien. Tujuan penelitian ini adalah untuk mengetahui hubungan penggunaan terapi levodopa dan kombinasi terhadap kualitas hidup serta mengidentifikasi faktor-faktor yang berhubungan dengan kualitas hidup. Penelitian ini menggunakan rancangan potong lintang. Subjek penelitian adalah pasien Parkinson rawat jalan di Poliklinik Saraf RSUD Arifin Achmad Pekanbaru, RSUP Dr. Hasan Sadikin Bandung, RSUD Cibabat Cimahi, dan RSAU Dr. Salamun Bandung pada periode Juli-Desember 2018. Pengukuran kualitas hidup dilakukan terhadap 33 subjek penelitian yang menerima terapi kombinasi dengan levodopa menggunakan kuesioner The 39-item Parkinson's Disease Questionnaire (PDQ-39) versi bahasa Indonesia. Analisis dilakukan dengan membandingkan rata-rata skor total PDQ-39 antarkelompok pada masing-masing variabel. Perbandingan nilai skor total PDQ-39 dianalisis dengan uji T tidak berpasangan dan uji one way ANOVA untuk melihat adanya perbedaan skor PDQ-39 antarkelompok variabel. Hasil analisis bivariat menunjukkan tidak terdapat perbedaan rata-rata skor total PDQ-39 antarkelompok terapi kombinasi dengan levodopa $(\mathrm{p}=0,262)$. Hasil analisis multivariat menunjukkan variabel yang secara independen berkorelasi dengan kualitas hidup adalah aktivitas olahraga $(\mathrm{r}=0,233)$, tingkat keparahan penyakit $(\mathrm{r}=0,464)$, dan komplikasi motorik $(\mathrm{r}=0,329)$. Berdasarkan hasil penelitian, dapat disimpulkan bahwa kualitas hidup pasien Parkinson tidak dipengaruhi oleh jenis pengobatan, namun dipengaruhi secara independen oleh aktivitas olahraga, tingkat keparahan penyakit, dan komplikasi motorik.
\end{abstract}

Kata kunci: Komplikasi motorik, kualitas hidup, levodopa, Parkinson

\section{Evaluation of Health-related Quality of Life in Patients with Parkinson's Disease: A Levodopa-based Therapy Approach}

\begin{abstract}
Levodopa has been the golden choice in the treatment of Parkinson's disease (PD) for more than 40 years. The administration of levodopa is often combined with other drugs to increase its bioavailability and effectiveness. However, long-term use of levodopa has been proven to cause side effects of motor complications that may reduce health-related quality of life (HRQoL). The purpose of this study was to determine the effect of levodopa with combination therapy on HRQoL and identify factors related to quality of life. This study was conducted by a crosssectional design. The research subjects were out-patients with PD in Arifin Achmad Pekanbaru Hospital, Dr. Hasan Sadikin Bandung Hospital, Cibabat Cimahi Hospital, and Dr. Salamun Bandung Hospital during the period of July to December 2018. Thirty-three subjects with minimum one year of treatment containing levodopa were assessed using an Indonesian-translated version of The 39-item Parkinson's Disease Questionnaire (PDQ-39). Mean score of PDQ-39 between treatments were calculated and the subgroup analyses (by baseline characteristics and occurrence of adverse events) were conducted using the same approach. The comparation of mean score of PDQ39 were analysed statistically using independent T-test and one way ANOVA. Bivariate analysis revealed there was no significant changes in mean score of PDQ-39 between treatment with levodopa combination $(p=0.262)$. Based on the result of multivariate analysis, variables that independently correlated to patient's quality of life were exercise $(\mathrm{r}=0.233)$, severity $(\mathrm{r}=0.464)$, and motor complications $(\mathrm{r}=0.329)$. Results suggest that total HRQoL in patients with PD was not significantly affected by variation of treatment but independently correlated to exercise, disease severity, and motor complications.
\end{abstract}

Keywords: Levodopa, motor complications, Parkinson's disease, quality of life

Korespondensi: Yasinda Oktariza, M.S.Farm., Apt., Sekolah Farmasi, Institut Teknologi Bandung, Bandung, Jawa Barat 40132, Indonesia, email: yasindaoktariza@gmail.com

Naskah diterima: 10 Mei 2019, Diterima untuk diterbitkan: 5 Desember 2019, Diterbitkan: 28 Desember 2019 


\section{Pendahuluan}

Penyakit Parkinson merupakan penyakit degenerasi fungsi otak dan peringkat kedua yang paling banyak diderita setelah penyakit Alzheimer. ${ }^{1}$ Penyakit Parkinson disebabkan oleh adanya penurunan jumlah dopamin di otak yang berperan dalam mengendalikan gerakan akibat kerusakan sel saraf di substansia nigra pars compacta $(\mathrm{SNc})$ di batang otak ${ }^{1}$ serta adanya agregasi protein abnormal berupa Lewy bodies, yang mengandung $\alpha$-synuclein. ${ }^{2}$ Penyakit Parkinson terjadi pada $1 \%$ populasi berusia di atas 60 tahun dengan prevalensi yang meningkat seiring meningkatnya usia. ${ }^{3,4}$ Morbiditas penyakit Parkinson terjadi pada 1-2 per 1000 orang populasi dan sebagian besar pada laki-laki dan kelompok usia lanjut. ${ }^{4}$ Di Indonesia, belum terdapat data resmi yang memublikasikan jumlah pasien Parkinson secara keseluruhan, namun demikian, penyakit Parkinson diperkirakan menyerang 1 per 272 orang populasi di Indonesia. ${ }^{5}$

Progresivitas penyakit Parkinson dapat bervariasi antara satu pasien dengan pasien lainnya. ${ }^{1}$ Karakteristik penyakit Parkinson ditandai oleh adanya gejala motorik dominan berupa tremor pada saat istirahat, rigiditas, bradikinesia, dan hilangnya refleks postural tubuh. Penyakit Parkinson juga berhubungan dengan gejala nonmotorik antara lain depresi, rasa cemas, halusinasi, psikosis, delusi, dan gangguan tidur yang diikuti dengan gejala motorik onset lambat seperti ketidakstabilan postural, kekakuan dalam gaya berjalan, serta kesulitan berbicara dan menelan. ${ }^{6}$ Hal ini menyebabkan pasien Parkinson sangat rentan mengalami penurunan kualitas hidup terkait kesehatan akibat gangguan motorik yang signifikan dan beban gejala nonmotorik yang menyertainya. $^{7}$

Pengobatan penyakit Parkinson bertujuan untuk meningkatkan level dopamin di otak dalam rangka memperbaiki gejala motorik dan memperlambat progresivitas penyakitnya.
Beberapa golongan obat utama yang banyak digunakan di dalam pengobatan simtomatik penyakit Parkinson antara lain berasal dari golongan prekursor dopamin (levodopa), agonis dopamin (bromokriptin, pramipeksol), inhibitor MAO-B (selegilin, rasagilin), inhibitor COMT (entakapon, tolkapon), serta golongan antikolinergik (benzatropin, triheksifenidil). ${ }^{8}$ Namun, pada kenyataannya obat-obat yang digunakan tersebut belum dapat menjadi solusi pengobatan untuk jangka panjang disebabkan terjadi penurunan efikasi seiring perkembangan neurodegenerasi saraf dopaminergik. ${ }^{8}$

Levodopa telah menjadi pilihan utama dalam pengobatan penyakit Parkinson selama lebih dari 40 tahun. ${ }^{9}$ Levodopa merupakan golongan prekursor dopamin yang dapat menembus sawar darah otak dan kemudian dikonversi menjadi dopamin di periferal oleh enzim aromatic L-amino acid decarboxylase (AADC). ${ }^{8}$ Banyak studi telah membuktikan efek dari levodopa dalam menurunkan gejala tremor, bradikinesia, dan rigiditas. ${ }^{9}$ Penggunaan levodopa sering dikombinasikan dengan obat lain agar dapat meningkatkan bioavailabilitas maupun efektivitasnya. Namun, efek samping pengobatan levodopa dalam jangka panjang dapat menimbulkan komplikasi motorik berupa fluktuasi motorik dan diskinesia yang dialami kebanyakan pasien. ${ }^{10,11}$ Pada pasien dengan terapi levodopa, 25-30\% pasien akan mengalami komplikasi motorik (fluktuasi motorik dan diskinesia) maupun nonmotorik (sensorik, otonomik, dan psikiatrik), 50\% akan timbul setelah 5 tahun, dan $80 \%$ akan timbul setelah 10 tahun. ${ }^{12}$ Efek samping yang terjadi akibat penggunaan dan kombinasi levodopa dengan obat lain tersebut tentu akan memengaruhi kualitas hidup pasien nantinya.

Penelitian ini bertujuan untuk mengetahui hubungan pemilihan terapi kombinasi levodopa dengan kualitas hidup serta faktor-faktor lain yang dapat memengaruhi kualitas hidup pasien Parkinson. Penelitian ini diharapkan dapat 
menjadi dasar bagi penelitian selanjutnya serta dapat digunakan sebagai pertimbangan dalam menentukan strategi penanganan pasien Parkinson di rumah sakit untuk meningkatkan kualitas hidup.

\section{Metode}

Penelitian ini merupakan penelitian analitik observasional menggunakan rancangan potong lintang yang dilakukan secara konkuren pada pasien Parkinson rawat jalan. Penelitian ini dilakukan di Poliklinik Saraf RSUD Arifin Achmad Pekanbaru, Poliklinik Saraf RSUP Dr. Hasan Sadikin Bandung, Poliklinik Saraf RSUD Cibabat Cimahi dan Poliklinik Saraf RSAU Dr. Salamun Bandung pada periode Juli-Desember 2018. Penelitian ini telah mendapatkan persetujuan dari Komite Etik Penelitian Kesehatan Rumah Sakit Umum Pusat Dr. Hasan Sadikin Bandung nomor LB.04.01/A05/EC/294/X/2018 (amandemen dari ethical approval nomor LB.04.01.A05/ EC/163/V/2018).

Subjek penelitian diambil dengan metode consecutive sampling yaitu pengambilan seluruh pasien Parkinson rawat jalan yang memenuhi kriteria inklusi dan bebas dari kriteria eksklusi dalam periode waktu tertentu. Kriteria inklusi meliputi pasien rawat jalan yang terdiagnosis penyakit Parkinson, lakilaki maupun perempuan, telah menerima terapi kombinasi levodopa yang sama minimal selama 1 tahun terakhir, dan bersedia ikut serta dalam penelitian dengan mengisi informed consent. Kriteria eksklusi meliputi pasien yang sedang menerima terapi yang dapat mengakibatkan induksi Parkinson sekunder secara bermakna, yakni seperti antipsikotik, antidepresan, antiepileptik, serta antiemetik, pasien yang mengalami gangguan komunikasi (tidak dapat mengikuti perintah), gangguan anggota gerak, Hoehn dan Yahr (HY) derajat 5, komplikasi stroke berat, demensia, serta tidak rutin kontrol atau data pasien tidak lengkap.

Instrumen yang digunakan pada penelitian ini adalah kuesioner PDQ-39, skala Hoehn dan Yahr (HY), serta Movement Disorder Society-sponsored revision of the Unified Parkinson's Disease Rating Scale, Part IVMotor complications (MDS-UPDRS Bagian IV). Kualitas hidup diperoleh dengan metode wawancara menggunakan kuesioner The 39item Parkinson's Disease Questionnaire (PDQ39). PDQ-39 dapat menjadi instrumen HRQoL yang tepat disebabkan skala kuesioner telah diuji dan memiliki karakteristik klinis yang memenuhi syarat serta telah digunakan dalam penelitian di berbagai negara dengan jumlah pasien yang besar. ${ }^{13}$ Tingkat keparahan pada penyakit pasien ditentukan dengan penilaian terhadap skala HY. MDS-UPDRS Bagian IV digunakan untuk mengevaluasi kejadian komplikasi motorik yang dapat muncul akibat pengobatan.

Penelitian ini diawali dengan uji validitas dan reliabilitas kuesioner PDQ-39. Kuesioner PDQ-39 yang telah diterjemahkan ke dalam bahasa Indonesia diujikan terhadap 31 pasien Parkinson rawat jalan yang berbeda dengan subjek yang akan diteliti. Hasil uji validitas kuesioner menunjukkan koefisien korelasi dapat diterima $(\mathrm{r}=0,470-0,892)$ dengan nilai reliabilitas yang tinggi $(\alpha=0,924)$.

Penelitian dilanjutkan dengan pengumpulan data yang diperlukan. Pengukuran kualitas hidup pasien Parkinson yang menjadi variabel tergantung dengan kuesioner PDQ-39 dinilai dengan rentang skor total yaitu 0-100 yang menyatakan bahwa semakin rendah skor total maka kualitas hidup pasien semakin baik. ${ }^{14}$ Tingkat keparahan pasien dikelompokkan ke dalam 5 derajat keparahan menggunakan skala HY. Evaluasi terkait adanya komplikasi motorik akibat pengobatan menggunakan MDS-UPDRS Bagian IV dilakukan dengan pengelompokan: tidak ada, ringan, sedang, dan berat. ${ }^{15}$ Pengumpulan data karakteristik lainnya dilakukan dengan pengambilan data 
melalui catatan rekam medis atau wawancara langsung terhadap pasien atau keluarga pasien.

Analisis data dilakukan menggunakan analisis bivariat dan multivariat. Analisis bivariat dilakukan dengan metode komparatif untuk menentukan hubungan antara variabel tergantung dan variabel bebas dua kelompok menggunakan uji $\mathrm{T}$ tidak berpasangan serta lebih dari dua kelompok dengan uji one way ANOVA. Variabel tergantung berupa skor total PDQ-39, sedangkan variabel bebas terdiri dari kombinasi terapi levodopa, komplikasi motorik, aktivitas sosial, aktivitas olahraga, durasi penyakit, serta tingkat keparahan penyakit. Hipotesis nol diterima apabila nilai signifikansi $\mathrm{p}>0,05$ dan interval kepercayaan IK95\% yang mencakup angka 0 menunjukkan tidak terdapat perbedaan yang signifikan secara statistik antarkelompok pada masing-masing variabel bebas terhadap skor PDQ-39 atau kualitas hidup. Analisis multivariat dilakukan dengan regresi linear untuk menganalisis adanya pengaruh secara simultan dari variabel bebas terhadap variabel tergantung. Analisis multivariat dilakukan untuk variabel yang memiliki nilai $\mathrm{p}<0,25$.

\section{Hasil}

Pada penelitian ini, diperoleh 33 pasien yang telah memenuhi kriteria inklusi dan eksklusi. Berdasarkan karakteristik pasien, terdapat $48,48 \%$ laki-laki, dengan rata-rata usia yaitu $61,030 \pm 9,122$ tahun, dan $66,67 \%$ pasien yang tidak memiliki riwayat pekerjaan. Diketahui bahwa 23 pasien $(69,70 \%)$ memiliki penyakit Parkinson dengan skala HY 3 dan 10 pasien (30,30\%) dengan skala HY 4. Distribusi pasien berdasarkan kelompok karakteristik dapat dilihat pada Tabel 1 dan 3 .

Pada penelitian ini, seluruh pasien menerima terapi levodopa dan kombinasi dengan obat lain. Terdapat empat macam kombinasi seperti yang tercantum pada Tabel 2. Jenis obat yang diberikan pada semua pasien adalah karbidopa/ benserazid dan triheksifenidil (THF).

Berdasarkan uji beda kualitas hidup pada tiap kelompok yang ditunjukkan dalam Tabel 3, tidak ditemukan perbedaan kualitas hidup antarkelompok pada variabel kelompok terapi dan aktivitas sosial $(\mathrm{p}>0,05)$. Perbedaan dalam kualitas hidup yang signifikan ditemukan pada variabel komplikasi motorik $(p<0,001)$,

Tabel 1 Karakteristik Umum Pasien

\begin{tabular}{|c|c|c|}
\hline Variabel & Jumlah (n=33) & Persentase (\%) \\
\hline \multicolumn{3}{|l|}{ Usia } \\
\hline$<60$ tahun & 16 & 48,48 \\
\hline$\geq 60$ tahun & 17 & 51,52 \\
\hline \multicolumn{3}{|l|}{ Jenis Kelamin } \\
\hline Laki-laki & 16 & 48,48 \\
\hline Perempuan & 17 & 51,52 \\
\hline \multicolumn{3}{|l|}{ Asuransi } \\
\hline Ya (BPJS) & 32 & 96,67 \\
\hline Tidak (Umum) & 1 & 3,03 \\
\hline \multicolumn{3}{|l|}{ Riwayat Pekerjaan } \\
\hline Bekerja & 22 & 66,67 \\
\hline Tidak bekerja & 11 & 33,33 \\
\hline \multicolumn{3}{|l|}{ Riwayat Pendidikan } \\
\hline Sekolah Dasar & 7 & 21,21 \\
\hline Sekolah Menengah Pertama & 7 & 21,21 \\
\hline Sekolah Menengah Atas/Sekolah Menengah Kejuruan & 8 & 24,24 \\
\hline Perguruan Tinggi & 11 & 33,33 \\
\hline
\end{tabular}


Tabel 2 Karakteristik Kombinasi Terapi

\begin{tabular}{clccc}
\hline $\begin{array}{c}\text { Kelompok } \\
\text { Terapi }\end{array}$ & \multicolumn{1}{c}{ Kombinasi Terapi } & $\begin{array}{c}\text { Rata-Rata } \\
\text { Dosis Levodopa } \\
(\mathbf{m g} / \mathbf{h a r i} \pm \text { SD) }\end{array}$ & $\begin{array}{c}\text { Jumlah } \\
(\mathbf{n = 3 3 )}\end{array}$ & $\begin{array}{c}\text { Persentase } \\
(\mathbf{\%})\end{array}$ \\
\hline T1 & Levodopa, benserazid, THF & $200 \pm 100$ & 3 & 9,10 \\
T2 & Levodopa, benserazid, pramipeksol, THF & $187,50 \pm 85,39$ & 4 & 12,12 \\
T3 & Levodopa, karbidopa, entakapon, THF & $254,17 \pm 49,81$ & 12 & 36,36 \\
T4 & Levodopa, karbidopa, entakapon, pramipexol, THF & $275 \pm 58,01$ & 14 & 42,42 \\
\hline
\end{tabular}

Keterangan: THF=triheksifenidil; SD=Standar Deviasi; Kekuatan sediaan=levodopa $100 \mathrm{mg}$, benserazid $25 \mathrm{mg} / \mathrm{karbidopa}$ $25 \mathrm{mg}$, entakapon $200 \mathrm{mg}$, pramipeksol 0,375 mg

aktivitas olahraga $(\mathrm{p}=0,022)$, durasi penyakit $(\mathrm{p}=0,001)$, dan tingkat keparahan penyakit $(\mathrm{p}<0,001)$.
Berdasarkan data seperti yang tercantum pada Tabel 4, dapat dilihat bahwa variabel yang secara independen berkorelasi dengan

Tabel 3 Hubungan Variabel-Variabel Terhadap Kualitas Hidup Pasien Parkinson

\begin{tabular}{|c|c|c|c|c|}
\hline Variabel & $\begin{array}{c}\text { Jumlah } \\
(n=33)\end{array}$ & $\begin{array}{c}\text { Skor Total } \\
\text { PDQ-39 (SD) }\end{array}$ & Nilai p & $\begin{array}{c}\text { Perbedaan } \\
\text { Rata-Rata (IK95\%) }\end{array}$ \\
\hline \multicolumn{5}{|c|}{ Kelompok Kombinasi Terapi ${ }^{b}$} \\
\hline $\mathrm{T} 1$ & 3 & $26,39(9,77)$ & 0,262 & - \\
\hline $\mathrm{T} 2$ & 4 & $33,76(11,84)$ & & \\
\hline $\mathrm{T} 3$ & 12 & $28,09(15,04)$ & & \\
\hline $\mathrm{T} 4$ & 14 & $39,49(17,16)$ & & \\
\hline $\begin{array}{l}\text { Komplikasi Motorik }{ }^{\mathbf{b}, \mathbf{d}} \\
\text { Tidak ada } \\
\text { Ringan } \\
\text { Sedang } \\
\text { Berat }\end{array}$ & $\begin{array}{r}14 \\
3 \\
8 \\
8\end{array}$ & $\begin{array}{c}24,22(11,88) \\
26,48(8,46) \\
34,46(10,77) \\
51,25(13,43)\end{array}$ & $<0,001^{*}$ & - \\
\hline $\begin{array}{l}\text { Diskinesia }^{\mathbf{a}} \\
\text { Ada } \\
\text { Tidak ada }\end{array}$ & $\begin{array}{l}12 \\
21\end{array}$ & $\begin{array}{l}43,11(16,36) \\
27,94(12,72)\end{array}$ & $0,006^{*}$ & $15,17(4,76-25,59)$ \\
\hline $\begin{array}{l}\text { Fluktuasi Motorik }^{\mathbf{a}} \\
\text { Ada } \\
\text { Tidak ada }\end{array}$ & $\begin{array}{l}17 \\
16\end{array}$ & $\begin{array}{l}41,31(15,50) \\
25,11(11,33)\end{array}$ & $0,002 *$ & $16,20(6,59-25,89)$ \\
\hline $\begin{array}{l}\text { Aktivitas Sosial }^{\mathbf{a}} \\
\text { Ada } \\
\text { Tidak ada }\end{array}$ & $\begin{array}{l}11 \\
22\end{array}$ & $\begin{array}{l}31,49(16,68) \\
34,44(15,57)\end{array}$ & 0,620 & $-2,95(-14,95-9,05)$ \\
\hline $\begin{array}{l}\text { Aktivitas Olahraga }{ }^{\mathbf{b}, \mathbf{c}} \\
\text { Dulu } \\
\text { Sekarang } \\
\text { Tidak pernah }\end{array}$ & $\begin{array}{r}13 \\
12 \\
8\end{array}$ & $\begin{array}{l}30,60(13,62) \\
27,98(12,87) \\
46,31(17,31)\end{array}$ & $0,022 *$ & - \\
\hline $\begin{array}{l}\text { Durasi Penyakit }^{\text {a }} \\
<5 \text { tahun } \\
\geq 5 \text { tahun }\end{array}$ & $\begin{array}{l}15 \\
18\end{array}$ & $\begin{array}{l}24,28(13,31) \\
41,11(13,59)\end{array}$ & $0,001^{*}$ & $\begin{array}{c}-16,83(-26,43- \\
(-7,23))\end{array}$ \\
\hline $\begin{array}{l}\text { Tingkat Keparahan (S) } \\
1 \\
2 \\
3 \\
4\end{array}$ & $\begin{array}{r}0 \\
0 \\
23 \\
10\end{array}$ & $\begin{array}{c}- \\
- \\
26,28(10,49) \\
49,98(13,34)\end{array}$ & $\begin{array}{c}- \\
- \\
<0,001 *\end{array}$ & $\begin{array}{c}- \\
- \\
-23,70(-32,50- \\
(-14,90))\end{array}$ \\
\hline
\end{tabular}


Tabel 4 Analisis Multivariat Regresi Linear

\begin{tabular}{lll}
\hline \multicolumn{1}{c}{ Parameter } & \multicolumn{1}{c}{ Hasil } & \multicolumn{1}{c}{ Keterangan } \\
\hline Model & $\begin{array}{l}\text { Didapatkan model yang terdiri } \\
\text { dari olahraga, severitas, dan } \\
\text { komplikasi motorik }\end{array}$ & $\begin{array}{l}\text { Model ini diperoleh setelah variabel durasi penyakit } \\
\text { dikeluarkan dari model secara bertahap dengan metode } \\
\text { backward }\end{array}$ \\
Adjusted $\mathrm{R} 2$ & $58,7 \%$ & $\begin{array}{l}\text { Kemampuan olahraga, severitas, dan komplikasi } \\
\text { motorik untuk menjelaskan skor PDQ-39 sebesar 58,7\% }\end{array}$ \\
Koefisien korelasi & $\begin{array}{l}\text { Olahraga }=0,233 \\
\text { Keveritas }=0,464\end{array}$ & $\begin{array}{l}\text { Kekuatan korelasi positif rendah/lemah } \\
\text { Kekuatan korelasi positif rendah/lemah }\end{array}$ \\
& Komplikasi motorik=0,329 & Kenang \\
\hline
\end{tabular}

kualitas hidup pasien yaitu aktivitas olahraga dengan koefisien korelasi positif lemah $(\mathrm{r}=0,233)$, severitas atau tingkat keparahan penyakit dengan koefisien korelasi positif sedang $(\mathrm{r}=0,464)$, dan komplikasi motorik dengan koefisien korelasi positif lemah $(\mathrm{r}=0,329)$. Hasil penelitian ini menunjukkan bahwa kombinasi terapi dengan levodopa tidak memiliki korelasi secara independen terhadap kualitas hidup dari pasien Parkinson, namun memiliki kolerasi secara independen terhadap aktivitas olahraga, tingkat keparahan penyakit, dan komplikasi motorik.

\section{Pembahasan}

Pemilihan terapi pada penyakit Parkinson dilakukan dengan berdasarkan beberapa faktor, seperti usia pasien, tingkat keparahan penyakit, tingkat disabilitas fungsional, status kognitif, serta efek samping yang berkaitan dengan obat. ${ }^{9}$ Seiring dengan perkembangan penyakit Parkinson, pengobatan harus disesuaikan untuk dapat memberikan efek pengendalian gejala yang optimal. Modifikasi pada regimen terapi diperlukan untuk mengatasi komplikasi motorik yang muncul selama pengobatan. Beberapa hal yang dapat dilakukan adalah meningkatkan atau menyesuaikan dosis agen dopaminergik sesuai dengan respon maupun toleransi dari pasien terhadap pengobatan, penambahan pengobatan dopaminergik lainnya, membagi dosis levodopa menjadi dosis yang lebih kecil dengan meningkatkan frekuensi pemberian (fraksinasi dosis levodopa), atau menambahkan inhibitor COMT (catecholO-methyltransferase), seperti entakapon atau tolkapon, untuk memperpanjang efek dari levodopa. ${ }^{16}$ Pengobatan penyakit Parkinson diharapkan dapat memperbaiki gejala-gejala simtomatik serta dapat memperbaiki kualitas hidup, dari perspektif pasien.

Penelitian ini menunjukkan bahwa tidak terdapat perbedaan rata-rata skor total PDQ39 yang bermakna antarkelompok kombinasi terapi $(\mathrm{p}=0,262)$. Diketahui bahwa seluruh subjek yang terlibat penelitian ini menerima levodopa dalam regimen terapinya. Adanya kombinasi obat lain dengan levodopa tidak memberikan perbedaan terhadap kualitas hidup pasien secara keseluruhan disebabkan pemilihan regimen terapi disesuaikan dengan progresivitas penyakit agar dapat memberikan kontrol gejala yang baik. Akan tetapi, secara keseluruhan terdapat peningkatan skor total PDQ-39 seiring dengan bertambahnya jumlah kombinasi obat yang diberikan. Hal ini dapat disebabkan kombinasi obat yang lebih banyak diberikan kepada pasien dengan komplikasi penyakit yang lebih berat. ${ }^{17}$ Beberapa studi serupa menunjukkan hasil yang sama bahwa tidak terdapat hubungan yang bermakna antara jumlah obat atau jenis pengobatan dengan skor total PDQ-39. ${ }^{18-20}$

Aktivitas sosial dalam penelitian ini meliputi kegiatan yang melibatkan interaksi pasien dengan orang lain di lingkungannya contohnya adalah arisan, pengajian, gotong 
royong, ataupun yang lainnya. Hasil analisis menunjukkan bahwa tidak terdapat perbedaan rata-rata skor PDQ-39 antara pasien yang melakukan aktivitas sosial dan pasien yang tidak melakukan aktivitas sosial. Pengaruh aktivitas sosial tergantung pada karakter dan respon dari masing-masing orang yang terlibat dalam aktivitas sosial tersebut dan bagaimana pasien dapat berinteraksi dengan baik dalam lingkungan sosialnya. Hal ini menyebabkan aktivitas sosial tidak memberikan pengaruh yang signifikan pada perbaikan kualitas hidup pasien.

Levodopa merupakan terapi standar yang telah lama digunakan sebagai pengobatan untuk penyakit Parkinson. Efek samping dopaminergik jangka pendek jarang terjadi dan biasanya akan hilang dengan sendirinya. Tetapi, terapi jangka panjang levodopa dapat menyebabkan komplikasi motorik pada sebagian besar pasien. ${ }^{10,11,21}$ Hasil penelitian ini menunjukkan bahwa komplikasi motorik baik yang berupa diskinesia maupun fluktuasi motorik berhubungan terhadap kualitas hidup. Analisis bivariat terhadap variabel komplikasi motorik menunjukkan paling tidak terdapat dua kelompok dengan rata-rata skor total PDQ39 yang berbeda bermakna $(p<0,001)$.

Analisis lebih lanjut terhadap variabel komplikasi motorik menggunakan post hoc Bonferroni menunjukkan terdapat perbedaan kualitas hidup antara kelompok "tidak ada vs berat", "ringan vs berat", dan "sedang vs berat". Namun, tidak terdapat pengaruh antara kelompok "tidak ada", "ringan", ataupun "sedang". Hal ini dapat disebabkan pasien yang menderita komplikasi berat cenderung tidak mampu untuk melakukan sebagian besar kegiatan sehingga berpengaruh secara signifikan terhadap kualitas hidup.

Terdapat beberapa faktor yang dapat meningkatkan risiko komplikasi motorik, seperti pasien dengan usia yang lebih muda, dosis levodopa yang lebih tinggi, serta pasien berjenis kelamin perempuan. ${ }^{22}$ Selain itu, pemberian kombinasi levodopa/karbidopa/ entakapon memiliki faktor risiko lebih tinggi terhadap kejadian diskinesia dibandingkan dengan kombinasi levodopa/karbidopa. ${ }^{22}$ Maka terhadap penelitian ini, kelompok Terapi 3 (T3) dan Terapi 4 (T4) pada Tabel 2 memiliki risiko munculnya komplikasi motorik yang lebih tinggi dibandingkan kelompok lainnya.

Faktor lain yang menjadi parameter dalam penelitian ini adalah aktivitas olahraga. Aktivitas olahraga meliputi semua aktivitas fisik terencana yang bertujuan menyehatkan tubuh seperti senam ringan, jalan-jalan santai, maupun cabang olahraga berat lain yang pernah dilakukan oleh pasien di masa lampau maupun saat ini. Analisis menggunakan post hoc Bonferroni menunjukkan bahwa terdapat perbedaan kualitas hidup antara kelompok pasien yang melakukan aktivitas olahraga pada saat ini dengan pasien yang tidak pernah melakukan aktivitas olahraga $(\mathrm{p}=0,026)$.

Aktivitas olahraga rutin dan terencana dapat menghasilkan perbaikan motorik dan fungsi kognitif terhadap pasien Parkinson dengan tingkat keparahan minimum hingga sedang. ${ }^{23,24}$ Sebuah penelitian eksperimental menunjukkan bahwa terdapat peningkatan keseimbangan pada pasien Parkinson setelah diberikan intervensi berupa senam Parkinson selama 2 minggu. ${ }^{25}$ Tai Chi merupakan salah satu aktivitas fisik yang aman dan efektif untuk pasien Parkinson dan telah terbukti dapat mengurangi gangguan keseimbangan dan risiko jatuh pada pasien. ${ }^{26}$ Tarian modern juga menunjukkan pengaruh positif terhadap kualitas hidup pasien Parkinson. ${ }^{27}$

Terdapat perbedaan rata-rata total skor PDQ-39 yang bermakna antara pasien yang menderita penyakit Parkinson selama kurang dari 5 tahun dan lebih dari 5 tahun $(p=0,001)$ dalam hasil penelitian ini. Seperti yang telah diketahui, penyakit Parkinson merupakan penyakit kronik neurodegeneratif dengan progresivitas yang meningkat seiring dengan bertambahnya usia. Semakin lama 
pasien menderita penyakit Parkinson, risiko peningkatan gejala pun semakin meningkat, baik gejala motorik maupun nonmotorik. Penggunaan obat jangka panjang juga dapat meningkatkan risiko efek samping yang tidak diinginkan yang dapat memengaruhi kualitas hidup pasien. Selain itu, pasien yang menderita penyakit Parkinson lebih lama cenderung lebih berisiko mengalami komplikasi motorik, hilangnya efek levodopa atau efek samping levodopa ${ }^{28}$ yang dapat berpengaruh terhadap kualitas hidupnya.

Hasil analisis bivariat variabel tingkat keparahan penyakit (skala HY) terhadap kualitas hidup pasien menunjukkan terdapat perbedaan rata-rata total skor PDQ-39 yang bermakna antara kelompok pasien dengan skala HY 3 dan skala HY $4(\mathrm{p}<0,00)$. Hasil penelitian ini sesuai dengan penelitian yang dilakukan oleh Amelia dkk. (2014) bahwa PDQ-39 memiliki korelasi yang signifikan dengan skala HY $(\mathrm{r}=0,74 ; \mathrm{p}<0,01) .{ }^{29} \mathrm{Hal}$ serupa juga dilaporkan oleh Lukas (2015) bahwa terdapat korelasi positif antara tingkat keparahan penyakit dengan skor total PDQ39. ${ }^{19}$ Hal ini dapat terjadi karena disabilitas yang berat akan membatasi mobilitas pasien yang pada akhirnya menyebabkan penurunan kualitas hidup. ${ }^{30}$

Hasil analisis multivariat menunjukkan variabel yang secara independen berkorelasi dengan kualitas hidup pasien antara lain aktivitas olahraga dengan koefisien korelasi positif lemah $(\mathrm{r}=0,233)$, severitas dengan koefisien korelasi positif sedang $(\mathrm{r}=0,464)$, dan komplikasi motorik dengan koefisien korelasi positif lemah $(\mathrm{r}=0,329)$. Kombinasi terapi dengan levodopa tidak berkorelasi secara independen terhadap kualitas hidup. Berdasarkan hasil tersebut, kombinasi terapi dengan levodopa dapat berhubungan dengan kualitas hidup pasien penyakit Parkinson bila dikaitkan dengan adanya komplikasi motorik akibat penggunaan terapi jangka panjang.

Untuk meningkatkan kualitas hidup pasien
Parkinson, diperlukan modifikasi regimen terapi yang bertujuan mengatasi komplikasi motorik yang muncul selama pengobatan yang cenderung akan lebih sulit untuk disembuhkan dibandingkan dengan gejala Parkinson itu sendiri. Modifikasi dapat dilakukan dengan cara meningkatkan atau menyesuaikan dosis levodopa maupun agen dopaminergik lain sesuai dengan respon maupun toleransi dari pasien terhadap pengobatan atau membagi dosis levodopa menjadi dosis yang lebih kecil dengan meningkatkan frekuensi pemberian (fraksinasi dosis levodopa). ${ }^{16}$ Selain itu, adanya aktivitas fisik berupa olahraga ringan atau fisioterapi rutin ${ }^{25}$ di masa awal perkembangan penyakit dapat menjadi komplemen terapi dengan levodopa sehingga kualitas hidup pasien dapat menjadi lebih baik.

Penelitian ini hanya menunjukkan ada atau tidaknya hubungan secara komparatif, namun tidak dapat menjelaskan hubungan sebab akibat. Perlu dilakukan penelitian dengan menggunakan desain kohort prospektif untuk meneliti hubungan sebab-akibat dari variabel aktivitas olahraga, tingkat keparahan penyakit, dan komplikasi motorik terhadap kualitas hidup pasien Parkinson. Selain itu, terdapat variabel lain yang tidak diikutsertakan yang memiliki kemungkinan untuk memengaruhi hasil penelitian, seperti pengaruh faktor gejala nonmotorik (ansietas dan depresi), kepatuhan pasien, dan sosioekonomi. Penelitian lanjutan seperti evaluasi pengaruh edukasi terhadap kepatuhan pasien dalam mengonsumsi obat dapat dilakukan guna mengetahui pengaruhnya terhadap kualitas hidup pasien Parkinson.

\section{Simpulan}

Pemilihan terapi kombinasi levodopa tidak berpengaruh terhadap kualitas hidup pasien Parkinson. Kualitas hidup pasien Parkinson dapat dipengaruhi oleh adanya komplikasi motorik akibat penggunaan levodopa jangka panjang selama pengobatan. Kualitas hidup 
juga tidak dipengaruhi oleh aktivitas sosial. Kualitas hidup pasien Parkinson dipengaruhi secara independen oleh aktivitas olahraga, tingkat keparahan penyakit, dan komplikasi motorik. Pemberian terapi Parkinson dengan levodopa sebaiknya diikuti dengan aktivitas fisik terencana untuk memperbaiki kondisi klinis pasien sehingga dapat meningkatkan kualitas hidup.

\section{Ucapan Terima Kasih}

Ucapan terima kasih disampaikan kepada seluruh staf, perawat, dan dokter di rumah sakit yang telah membantu dalam pengumpulan data yang diperlukan untuk penelitian ini.

\section{Pendanaan}

Penelitian ini sepenuhnya didanai oleh Lembaga Pengelola Dana Pendidikan (LPDP) Kementerian Keuangan Republik Indonesia.

\section{Konflik Kepentingan}

Seluruh penulis menyatakan tidak terdapat potensi konflik kepentingan dengan penelitian, kepenulisan (authorship), dan atau publikasi artikel ini.

\section{Daftar Pustaka}

1. Perhimpunan Dokter Indonesia. Panduan praktik klinis neurologi. Jakarta: Perhimpunan Dokter Spesialis Saraf Indonesia; 2016.

2. Kalia LV, Lang AE. Parkinson's disease. Lancet. 2015;386(9996):896-912. doi: 10. 1016/S0140-6736(14)61393-3.

3. Pringsheim T, Jette N, Frolkis A, Steeves TD. The prevalence of Parkinson's disease: A systematic review and meta-analysis. Mov Disord. 2014;29(13):1583-90. doi: $10.1002 / \mathrm{mds} .25945$.

4. Tysnes OB, Storstein A. Epidemiology of Parkinson's disease. J Neural Transm. 2017;124(8):901-5. doi: 10.1007/s00702 -017-1686-y

5. Setyono J, Noviani E, Gunarto U. Hubungan antara merokok dengan penyakit Parkinson di RSUD Prof. DR. Margono Soekarjo Purwokerto. Mandala Health. 2010;4(2):81-6.

6. World Health Organization. Neurological disorders: Public health challenges. Switzerland: WHO Press; 2006.

7. Kadastik-Eerme L, Rosenthal M, Paju T, Muldmaa M, Taba P. Health-related quality of life in Parkinson's disease: A cross-sectional study focusing on nonmotor symptoms. Health Qual Life Out. 2015;13(1):83. doi: 10.1186/s12955-0150281-X

8. Ellis JM, Fell MJ. Current approaches to the treatment of Parkinson's disease. Bioorg Med Chem Lett. 2017;27(18):4247-55. doi: 10.1016/j.bmcl.2017.07.075

9. Hauser RA. Levodopa: Past, present, and future. Eur Neurol. 2009;62(1):1-8. doi: $10.1159 / 000215875$

10. López IC, Ruiz PJ, del Pozo SV, Bernardos VS. Motor complications in Parkinson's disease: Ten year follow-up study. Mov Disord. 2010;25(16):2735-9. doi: $10.1002 / \mathrm{mds} .23219$

11. Manson A, Stirpe P, Schrag A. Levodopainduced-dyskinesias clinical features, incidence, risk factors, management and impact on quality of life. J Parkinsons Dis. 2012;2(3):189-98. doi: 10.3233/JPD $-2012-120103$

12. Kelompok Studi Movement Disorder PERDOSSI. Buku panduan tatalaksana penyakit Parkinson dan gangguan gerak lainnya. Jakarta: PERDOSSI; 2015.

13. Soh SE, McGinley J, Morris ME. Measuring quality of life in Parkinson's disease: Selection of-an-appropriate health- related quality of life instrument. Physiotherapy. 2011;97(1):83-9. doi: 10. 
1016/j. physio.2010.05.006.

14. Zhang JL, Chan P. Reliability and validity of PDQ-39: A quality-of-life measure for patients with PD in China. Qual Life Res. 2012;21(7):1217-21. doi: 10.1007/s1113 6-011-0026-1.

15. Martínez-Martín $\mathrm{P}$, Rodríguez-Blázquez C, Alvarez M, Arakaki T, Arillo VC, Chaná $\mathrm{P}$, et al. Parkinson's disease severity levels and MDS-Unified Parkinson's Disease Rating Scale. Parkinsonism Relat Disord. 2015;21(1):50-4. doi: 10.1016/j. parkreldis.2014.10.026.

16. Connolly BS, Lang AE. Pharmacological treatment of Parkinson disease: A review. J Am Med Assoc. 2014;311(16):1670-83. doi: 10.1001/jama.2014.3654.

17. National Institute for Health and Clinical Excellence. NICE guideline: Parkinson's disease in adults. United Kingdom; 2017.

18. Hendrik LN. Depresi berkorelasi dengan rendahnya kualitas hidup pasien Parkinson (tesis). Bali: Universitas Udayana; 2013.

19. Lukas A. Korelasi antara ansietas, depresi, dan gangguan kognitif terhadap kualitas hidup penderita penyakit Parkinson (tesis). Yogyakarta: Universitas Gadjah Mada; 2015.

20. Anindyta MA. Perbandingan kualitas hidup pasien Parkinson subtipe tremor dominant dan postural instability gait disorder (tesis). Yogyakarta: Universitas Gadjah Mada; 2017.

21. Ikawati Z. Farmakoterapi penyakit sistem syaraf pusat. Yogyakarta: Bursa Ilmu; 2014.

22. Warren OC, Kieburtz K, Rascol O, Poewe W, Schapira AH, Emre M, et al. Factors predictive of the development of Levodopa-induced dyskinesia and wearingoff in Parkinson's disease. Mov Disord. 2013;28(8):1064-71. doi: 10.1002/mds.2 5364.

23. Shulman LM, Katzel LI, Ivey FM,
Sorkin JD, Favors K, Anderson KE, et al. Randomized clinical trial of 3 types of physical exercise for patients with Parkinson disease. JAMA Neurol. 2013;70(2):183-90. doi: 10.1001/jamane urol.2013.646.

24. Petzinger GM, Fisher BE, McEwen S, Beeler JA, Walsh JP, Jakowec MW. Exercise-enhanced neuroplasticity targeting motor and cognitive circuitry in Parkinson's disease. Lancet Neurol. 2013;12(7):71626. doi: 10.1016/S1474-4422(13)70123-6

25. Muawanah S. Pengaruh metode senam Parkinson untuk meningkatkan keseimbangan pada pasien Parkinson's disease. J Ilmiah Fisioterapi. 2018;1(1): $38-43$.

26. Li F, Harmer P, Fitzgerald K, Eckstrom E, Stock R, Galver J, et al. Tai chi and postural stability in patients with Parkinson's disease. N Engl J Med. 2012;366(6):5119. doi: 10.1056/NEJMoa1107911

27. Westheimer O. Why dance for Parkinson's disease. Top Geriatr Rehabil. 2008;24(2): 127-40. doi: 10.1097/01.TGR.00003189 00.95313.af

28. Okun MS. Management of Parkinson disease in 2017: Personalized approaches for patient-specific needs. J Am Med Assoc. 2017;318(9):791-2. doi: 10.1001/ jama.2017.7914.

29. Amelia D, Syamsudin T, Ganiem AR. Penilaian kualitas hidup pasien Parkinson menggunakan PDQ-39 dan korelasinya dengan tingkat keparahan penyakit. Neurona. 2014;31(3).

30. Post B, Muslimovic D, van Geloven N, Speelman JD, Schmand B, de Haan RJ, et al. Progression and prognostic factors of motor impairment, disability and quality of life in newly diagnosed Parkinson's disease. Mov Disord. 2011;26(3):449-56. doi: $10.1002 / \mathrm{mds} .23467$. 